\title{
Effects of Stamped Charging on the Strength of Coke from the Weakly Caking Australian Agro-Allied Coal Blend Mixed with Coke Breeze
}

\author{
A.B. Adahama ${ }^{2}$, A.O Adeleke ${ }^{1}$, A.O. Olulana ${ }^{2}$, S.A. Ibitoye ${ }^{1}$ \\ ${ }^{1}$ Dept. of Materials Science \& Engineering, \\ Obafemi Awolowo University, Ile-Ife. Nigeria. \\ Email: aoadeleke2002@yahoo.com \\ ${ }^{2}$ National Metallurgical Development Centre (NMDC), \\ P.M.B 2116, Jos. Nigeria.
}

\begin{abstract}
The weakly caking Australian Agro-Allied coal sample mixed with 7\% un-reactive coke breeze was subjected to stamped charging prior to carbonization for 22 hours in a $250 \mathrm{~kg}$ pilot plant to improve the resulting coke strength. The coal was carbonized with a bulk density of $1,000 \mathrm{~kg} / \mathrm{m}^{3}$ and heating flue temperature of $1,340^{\circ} \mathrm{C}$. The screen distribution analysis and the micum tests conducted on the coke gave $M_{10}$ and $M_{40}$ of $15.90 \%$ and $73.20 \%$, respectively. These results show that the Agro-Allied coke produced is inferior to the coke from a normal top charged counterpart with $M_{10}$ and $M_{40}$ indices of $15.40 \%$ and $78.20 \%$, respectively and do not satisfy the requirements for the blast furnace ironmaking process. These results thus suggest that the stamped charging coking improvement method designed for high caking, high volatile coals may not be able to improve the strength of coke resulting from a weakly caking, medium volatile coal mixed with coke breeze.
\end{abstract}

Keywords: coal, caking, stamped, carbonization, coke, micum

\section{INTRODUCTION}

Coking coal to produce metallurgical grade coke comes from the bituminous grade coals, which constitutes about $52 \%$ of the world's resources of coals. However, only about $5 \%$ of the world's supply of coals is prime coking and suitable for straight carbonization [1,2]. Coke is an essential input in blast furnace iron production. Consequently, the volume of coke produced and used 
depends on the blast furnace activity. For instance, as at 1973 when the blast furnace iron output was 96.2 million in the United States, blast furnace coke consumption was 60.7 million tons [3]. When coal is heated, it softens when heat breaks the coal structure producing liquids and gases. The evolved low molecular weights components of the coal may escape as gases, while some molecules may condense as a complex mixture of liquids called tars and the large molecular weight species may re-combine and solidify as coke [4].

A coking coal is required to have low ash content because a large amount of inorganic material can dilute the plastic stage, adversely affecting coke formation. The coal should also contain low sulphur to reduce the amount of this heteroatom that may get into iron and reduce its mechanical strength $[4,5]$. Bench and pilot scale studies are normally conducted on coal blends prior to industrial scale cokemaking in a battery of ovens. Several coking techniques such as preheating, stamped charging and partial briquetting have been developed to improve the micum strength of coke from coal blends [6].

Coke breeze is the fine screening that result from the crushing of coke. Coke breeze typically passes a 0.5 inch or 0.25 inch screen opening. It has been estimated that a coke plant typically produces 4.3 tons of coke breeze for 134 tons of furnace coke [7]. The addition of coke breeze to coal blends allows the use of high volatile coal (and poor caking coals) as up to $70 \%$ of blend. Coal blends containing coke breeze produces coke with higher lumpiness and improved resistance to fissuring but with a slightly reduced abrasion resistance [8].

The aim of this research is to determine the micum strength obtainable in carbonizing the imported weakly caking Australian Agro-Allied coal (mixed with coke breeze) and assess the usability or otherwise of the resultant coke when the blast furnace at the Nigerian Ajaokuta steel plant begin operation.

\section{MATERIALS AND METHODS}

\subsection{Materials}

Drums of Agro-Allied coal blend imported from Australia and coke breeze by-product at the Coke Oven pilot plant, National Metallurgical Development Centre (NMDC), Jos, Nigeria.

\subsection{Methods}

The coal sample was carbonized in a $250 \mathrm{~kg}$ coke oven plant and the coke produced was subjected to screen distribution analysis and micum drum tests to determine the micum strength.

\subsection{Pilot scale coal carbonization}

The as-received coal was subjected to further crushing to obtain a sieve analysis such that $>3 \mathrm{~mm}$ size fraction is $>70 \%$ and $<0.5 \mathrm{~mm}$ is $\leq 35 \%$. The bulk density test was performed to obtain a bulk density in the range 690 to $760 \mathrm{~kg} / \mathrm{m}^{3}$. The coal was then mixed with $7 \%$ weight percent coke breeze and subjected to stamping in the steel stamping box to increase 
the bulk density to $1000 \mathrm{~kg} / \mathrm{m}^{3}$ and the cake formed was pushed into the coke oven for carbonization.

During carbonization, the temperatures of the six heating flues were maintained at $1,340^{\circ} \mathrm{C}$ by careful adjustment of air/liquefied petroleum gas ratio, at a heating rate of $1.1^{\circ} \mathrm{C} / \mathrm{min}$. The charge temperature rose progressively from $60^{\circ} \mathrm{C}$ to about $1250^{\circ} \mathrm{C}$ within a carbonization period of 22 hours. The coke produced was pushed into a quenching facility where cooling was done for about 3 hours by water circulating in the system but not in direct contact with the coke.

The coke produced was then stabilized by dropping the coke from a hopper placed at a height of 5.6m. Afterwards, the stabilized coke were screened through round hole sieves $0-10,10$ $-20,20-40,40-60,60-80$ and $+80 \mathrm{~mm}$ in a vibrating screening machine. For micum test, $50 \mathrm{~kg}$ sample obtained from selected screen fractions specified proportions was charged into a micum drum where it was subjected to rotation at a rate of 25 revolutions per minute for 4 minutes. The coke product of this test was screened again on the vibrating screen machine to determine the $\mathrm{M}_{10}$ and $\mathrm{M}_{40}$ indices that indicate coke mechanical strength.

\section{RESULTS AND DISCUSSION}

\subsection{Results}

The carbonization conditions used are presented in Table 1, while the results of screen distribution analysis and micum drum tests are shown in Tables 2 and 3, respectively.

Table 1. Carbonization conditions for the stamped Agro-Allied coal.

\begin{tabular}{|l|l|l|}
\hline S/No & Coking parameters & Agro-Allied coal \\
\hline 1. & Weight of charge $(\mathrm{kg})$ & 248.95 \\
\hline 2. & Bulk density $\left(\mathrm{kg} / \mathrm{m}^{3}\right)$ & 1,000 \\
\hline 3. & Flue temperature $\left({ }^{\circ} \mathrm{C}\right)$ & 1,340 \\
\hline 4. & Carbonization time (hours) & 22 \\
\hline
\end{tabular}


Table 2. Screen Distribution Analysis of Agro-Allied coke.

\begin{tabular}{|c|c|c|c|}
\hline $\mathbf{S} / \mathbf{N}$ & Sieve Sizes $(\mathbf{m m})$ & $\mathbf{W t} \mathbf{( k g )}$ & \% \\
\hline 1 & -10 & 9.80 & 5.49 \\
\hline 2. & $+10-20$ & 3.75 & 2.10 \\
\hline 3. & $+20-40$ & 4.70 & 2.63 \\
\hline 4. & $+40-60$ & 7.70 & 4.32 \\
\hline 5. & $+60-80$ & 17.30 & 9.70 \\
\hline 6 & +80 & 135.15 & 75.76 \\
\hline & Total weight retained & 178.40 & \\
\hline
\end{tabular}

Table 3. Micum indices of Agro-Allied coke.

\begin{tabular}{|l|l|l|}
\hline 5. & Micum 10 (M10) \% & $15.90 \%$ \\
\hline 6. & Micum 40 (M40)\% & $73.20 \%$ \\
\hline
\end{tabular}

\subsection{Discussion of Results}

The volatile matter (daf) of $30.2 \%$ determined for the Agro-Allied coal blend is less than the $33 \%$ required to necessitate stamped charging and coke breeze addition prior to carbonization in the German Zentralkokerei Saar plant $[8,9]$. Thee free swelling index of 2.5 for the Agro-Allied coal is also lower than the value of 6.5 for the German blend. The $7 \%$ coke breeze added to the Agro-Allied coal is higher than 5\% for the German blend $[8,9]$. These results indicate that both the volatile content and the caking value of the Agro-Allied coal do not necessitate its stamped charging carbonization with coke dust additions. The more expensive stamped charging carbonization with coke breeze additions are applied to high caking and high volatile coals to reduce the possibility of crack formation during carbonization and improve coke strength [8].

The bulk density of $1,000 \mathrm{~kg} / \mathrm{m}^{3}$ used for the stamped charged Agro-Allied coke is higher than the 800 to $820 \mathrm{~kg} / \mathrm{m}^{3}$ employed at UK Coke Research Establishment (CRE) for normal top charging of coals. The latter bulk density for normal top charging has been reported to offer a greater margin of safety as regards internal pressure generation than opting for the lower mean density of 720 to $750 \mathrm{~kg} / \mathrm{m}^{3}$ [10]. The bulk density of coal charge has been found to have great effects on internal pressure generation in the coke oven. It has been suggested that coking pressure is related to the fifth power of bulk density [10]. The stamped density for the AgroAllied coal is lower than the $1,200 \mathrm{~kg} / \mathrm{m}^{3}$ for stamped charge carbonization in the German Zentralkokerei Saar plant [8] but similar to 800 to $1,000 \mathrm{~kg} / \mathrm{m}^{3}$ used for preheating/stamped charging in China [5]. It is also within the range of 800 to $1,160 \mathrm{~kg} / \mathrm{m}^{3}$ for stamped charge coal in India. The high bulk density allow the coal particles to come closer together thus facilitating effective bonding of inert particles by the plastic mass [11]. These results strongly suggest that the bulk density used at NMDC for the successful carbonization of Agro-Allied stamped coal is 
appropriate and the absence of excessive pressure generation during the carbonization showed that the bulk density selected was appropriate.

The first phase of lateral shrinkage of coke during coal carbonization has been shown to depend on the charge bulk density and coal composition, while the second phase is controlled by coking time and coking rate. The second phase of contraction was reported to be almost the same for all the coals carbonized, while the total internal contraction was found to decrease with increasing charge bulk density [8]. The bulk density of $800 \mathrm{~kg} / \mathrm{m}^{3}$ produced lateral contraction of about $13.5 \mathrm{~mm}$, while a charge density of $680 \mathrm{~kg} / \mathrm{m}^{3}$ gave about $18 \mathrm{~mm}$ [12]. The bulk density of $1,000 \mathrm{~kg} / \mathrm{m}^{3}$ for the carbonization of Agro-Allied coal exceeds the range of 790 to $850 \mathrm{~kg} / \mathrm{m}^{3}$ for carbonization at Krupp Mannesmam coke oven battery [13] The size consists requirement of mixture of coal particles of $>3.0 \mathrm{~mm}$ and $<0.5 \mathrm{~mm}$ used for the carbonization of the Agro-Allied coal at NMDC is similar (though of different proportions) to $>3.15 \mathrm{~mm},<2.0 \mathrm{~mm}$ and $<0.5 \mathrm{~mm}$ mixture used at the German Krupp Mannessmann Coke oven for carbonization of coals [13]. These results show that the charge density employed for the stamped Agro-Allied coal may produce a coke with a lateral contraction lower than $13.5 \mathrm{~mm}$ and with no adverse effect on the coke oven refractory linings.

The heating flue temperature of $1,340^{\circ} \mathrm{C}$ used at the NMDC coke oven for the carbonization of the stamped Agro-Allied cake is higher than $1,200^{\circ} \mathrm{C}$ used at Wuhan, China but the same as $1,340^{\circ} \mathrm{C}$ at the German Zentralkokerei Saar plant [5,8]. These results indicate that the carbonization of the stamped cake at NMDC was conducted at a flue temperature that falls within the range for standard practice in the steel industries.

The $\mathrm{M}_{10}$ abrasion resistance of $15.9 \%$ determined for Agro-Allied coke with coke breeze addition is far higher (and thus the coke has a poorer abrasion resistance) than $6.2 \%$ for the German coke from the stamped charge cake of $33 \%$ volatile matter plus coke breeze. The $\mathrm{M}_{40}$ of $73.2 \%$ determined for the Agro-Allied coke is lower (thus, lower resistance to fissuring) than 76.9\% for the German coke [5]. The micum 10 for Agro-Allied coke is also lower than 5.3 to $5.5 \%$ determined for some Indian stamped coal blends coke [14]. The micum strength of the coke is also lower than the specification of $9 \%$ (maximum) $\mathrm{M}_{10}$ and $78.8 \%$ (minimum) $\mathrm{M}_{40}$ for coke for the blast furnace ironmaking at the Ajaokuta steel plant, Nigeria [15]. The micum 10 strength parameter determined for the Agro-Allied coke is also inferior to the $9 \%$ (maximum) and $5 \%$ to $8 \%$ specified for Phione steel plant and European steel mills, respectively $[16,17]$. The micum strength determined for the stamped Agro-Allied coke is also inferior to the $15.40 \%$ and $78.20 \%$ for the coke from the Agro-Allied coal normally top charged under slightly different conditions which include a lower coking time of 16 hours [8]. These results show that although stamped charging has been proved to be effective in improving coke strength of high volatile coals with high free swelling indices by eliminating the incidence of crack formation, it is not appropriate for a medium volatile, low caking coal such as Agro-Allied with coke dust addition.

The coking time of 22 hours used for the carbonization of the Agro-Allied coals far exceeds the range of 18 to 20 hours used for carbonization at the Taranto steel works coke oven battery [18]. The coking period of 22 hours is also 2.5 hours higher than the 19.5 hours used for carbonizing stamped coal in the German Zentralkokerei Saar plant [8], but fall within the range of 18 to 24 hours for typical German practice [19]. The coking periods used for the pilot scale carbonization 
of Agro-Allied coals thus fall within the range for standard coking practice in recognized steel industries and the result of micum drum test in the coke produced are thus likely to be reliable indices of Agro-Allied coke strength.

\section{CONCLUSIONS}

The weakly caking Agro-Allied coal mixed with $7 \%$ coke breeze was subjected to stamped charging prior to carbonization for 22 hours according to standard practice to improve its coke strength. The results obtained from proximate analysis and crucible swelling tests showed that the coal is a medium volatile, low caking coal for which the application of the more expensive stamped charging with coke breeze addition is in-appropriate. The micum strength 10 and 40 of $15.90 \%$ and $73.20 \%$ obtained for the resultant coke is inferior to the $15.40 \%$ and $78.20 \%$ determined for the normally charged Agro-Allied blend carbonized for 16 hours. These results showed that the application of the stamping coking improvement method may not lead to improved coke strength for a medium volatile, low caking coal mixed with the un-reactive coke breeze, particularly when carbonized at more than 16 hours.

\section{REFERENCES}

[1] http://www.worldcoal.org, $5^{\text {th }}$ September, 2007

[2] Bujnowska B. and Collins, G.1992. "Coal tar pitch for improving coking properties of coal", $2^{\text {nd }}$ International Cokemaking Congress, London, Vol. 2, pp.93-116.

[3] Hogan,W.T., 1992. "Coke in the United States: Capital investment and needed capacity for the 1990s", $2^{\text {nd }}$ International cokemaking congress, London, Vol. 1, pp.55-60.

[4] Krivandin, V. and Markov, B., 1980, Metallurgical Furnaces, $1^{\text {st }}$ edn., Mir Publishers, Moscow.

[5] Lu, Q and Li, Z., 1987. "The coke properties and coking mechanism of preheating-stamping process", $I^{\text {st }}$ International Cokemaking Congress, Essen, Supplementary volume, Section II.2.

[6] Moitra, A.K., Banerjee, N.G.,Shrinkhande, K.Y., Sing, K., Raja, K. and Banerjee, S., 'Studies on coal carbonization in India', $1^{\text {st }}$ edn., Central Fuel Research Institute publication, Calcutta (1972).

[7] http://www.ohiocitizen.org/campaigns/coke/maumee_05.24.2004.htm, 30 ${ }^{\text {th }}$ Auggust, 2008

[8] Echterhoff, J., Killich, H.J., Frick, H., Kuyumcu, H.Z. and Petak, H., 1992. "Production of blast furnace coke by stamp charging and utilization of recycled coke breeze", $2^{\text {nd }}$ International cokemaking congress, London, Vol. 2, pp.172-189.

[9] Adeleke, A.O, Olulana, A.O, Adahama, A.B., Ibitoye, S.A., 2007. "Study on the Reliability of Coke Research Establishment Micum 40 formula to predict coke mecum 40 at the Ajaokuta steel plant, Nigeria", Journal of Minerals \& Materials Characterization \& Engineering, Vol. 6, No. 2, pp. 135-142.

[10] Tucker, J. and Everitt, G.,1992. "Coking pressure -its causes, measurement and control." $2^{\text {nd }}$ International cokemaking congress, London, Vol.2, pp. 40-61.

[11] Parthasarathy, R.P., Sharma, R.P., Ghosh, N.B. and Raju, V.U.,1992. "Coal selection and preparation steps towards improving coke quality in SAIL", $2^{\text {nd }}$ International cokemaking congress, London, vol. 2, pp.152-171.

[12] Addes, V.I., 'Study of coal charge lateral contraction related to the pushing performance'. In Proc. $2^{\text {nd }}$ International cokemaking congress, London, pp.70-92 (1992). 
[13]Beckmann, R. and Meyer, G., 'Seven years of operating experience with the world's largest coke oven battery at Krupp Mannesmann Steelworks. In Proc. $2^{\text {nd }}$ International cokemaking congress, London, Vol. 1, pp.62-92 (1992).

[14] Prasad, H.N. ,Rao, P.V.T., Podder, N.N. and Chaterjee, A., 'Selection of coals by classical top charging'. In Proc. $2^{\text {nd }}$ International cokemaking congress, London, Preprints vol.1, pp.231235 (1992).

[15] Raw Materials Specifications, 1994, for Federal Government Steel Companies, $1^{\text {st }}$ edn., pp.6.

[16] http://www.phione.co.uk/coke/\#kinds_of_coke, $14^{\text {th }}$ January, 2008.

[17] http://www.jellinbah.com.au/libraryFiles/Jellinbah, $14^{\text {th }}$ January, 2008

[18] Salvatore, E., Capogrosso, L., de Franco, F. and Barnaba, P.,' Strategy of Ilva Taranto works on the coke and coal use in ironmaking'. In Proc. $2^{\text {nd }}$ International cokemaking congress, London, Vol. 2, pp. 93-114 (1992).

[19] National Metallurgical Development Centre(NMDC) Trainees' Report, on pilot scale carbonization study at Deutsche Montane Technologie(DMT), Germany (1992). 